\author{
Federal Reserve Bank of Dallas \\ Globalization and Monetary Policy Institute \\ Working Paper No. 172 \\ http:/ / www.dallasfed.org/ assets/ documents/ institute/ wpapers/ 2014/ 0172.pdf
}

\title{
Trade Linkages and the Globalisation of Inflation in Asia and the Pacific ${ }^{*}$
}

\author{
Raphael Auer \\ Swiss National Bank \\ Aaron Mehrotra \\ Bank for International Settlements
}

April 2014

\begin{abstract}
Some observers argue that increased real integration has led to greater co-movement of prices internationally. We examine the evidence for cross-border price spillovers among economies participating in the pan-Asian cross-border production networks. Starting with country-level data, we find that both producer price and consumer price inflation rates move more closely together between those Asian economies that trade more with one another, ie that share a higher degree of trade intensity. Next, using a novel data set based on the World Input-O utput D atabase (WIOD), we examine the importance of the supply chain for crossborder price spillovers at the sectoral level. We document the increasing importance of imported intermediate inputs for economies in the Asia-Pacific region and examine the impact on domestic producer prices of changes in costs of imported intermediate inputs. O ur results suggest that real integration through the supply chain matters for domestic price dynamics in the Asia-Pacific region.
\end{abstract}

JEL codes: E31, F4, F14, F15, F62

\footnotetext{
* Raphael Auer, Swiss National Bank, Börsenstr. 15, P.O. Box Ch-8022, Zürich, Switzerland. + 41-44-63138-84. raphael.auer@snb.ch. Aaron Mehrotra, Bank for International Settlements, Centralbahnplatz 2, 4051 Basel, Switzerland. aaron.mehrotra@bis.org. This paper was previously published as BIS Working Paper no 447. The research was conducted while Raphael Auer was visiting the BIS Representative Office for Asia and the Pacific. Emese Kuruc, Bat-el Berger and Pierre-Yves Deléamont provided excellent research assistance. We are grateful to the anonymous referees, participants at a seminar at the BIS, the People's Bank of China-BIS Research Conference on Globalisation and Inflation Dynamics in Asia and the Pacific, the CityU-JIMF International Conference on Pacific Rim Economies and the Evolution of the International Monetary Architecture, Eli Remolona, James Yetman, and our discussants Toshitaka Sekine and Xuan Song Tam for very helpful comments and suggestions. The views in this paper are those of the authors and do not necessarily reflect the views of the Swiss National Bank, the Bank for International Settlements, the Federal Reserve Bank of Dallas or the Federal Reserve System.
} 


\title{
Trade linkages and the globalisation of inflation in Asia and the Pacific ${ }^{1}$
}

\author{
Raphael A Auer ${ }^{\mathrm{a}}$ and Aaron Mehrotra ${ }^{\mathrm{b}}$
}

\author{
a Swiss National Bank, ETH Zurich, CEPR, and CESifo. Swiss National Bank, Börsenstrasse \\ 15, 8022 Zurich, Switzerland. E-mail: raphael.auer@snb.ch. \\ ${ }^{\mathrm{b}}$ Bank for International Settlements, Representative Office for Asia and the Pacific, 78th \\ floor, 2 IFC, 8 Finance Street, Central, Hong Kong SAR. E-mail: aaron.mehrotra@bis.org.
}

\begin{abstract}
Some observers argue that increased real integration has led to greater co-movement of prices internationally. We examine the evidence for cross-border price spillovers among economies participating in the pan-Asian cross-border production networks. Starting with country-level data, we find that both producer price and consumer price inflation rates move more closely together between those Asian economies that trade more with one another, ie that share a higher degree of trade intensity. Next, using a novel data set based on the World Input-Output Database (WIOD), we examine the importance of the supply chain for cross-border price spillovers at the sectoral level. We document the increasing importance of imported intermediate inputs for economies in the Asia-Pacific region and examine the impact on domestic producer prices of changes in costs of imported intermediate inputs. Our results suggest that real integration through the supply chain matters for domestic price dynamics in the Asia-Pacific region.
\end{abstract}

Keywords: globalisation, inflation, Asian manufacturing supply chain, price spillovers

JEL classification: E31, F4, F14, F15, F62

\section{Introduction}

Some observers argue that increased real integration, ie increased international trade in goods and services, has led to greater co-movement of prices internationally. This could occur directly, through import prices, or more indirectly, due to the effect of increased

\footnotetext{
${ }^{1}$ The views expressed in this paper are those of the authors and do not necessarily reflect those of the Bank for International Settlements or the Swiss National Bank. This paper was previously published as BIS Working Paper no 447. The research was conducted while Raphael Auer was visiting the BIS Representative Office for Asia and the Pacific. Emese Kuruc, Bat-el Berger and Pierre-Yves Deléamont provided excellent research assistance. We are grateful to the anonymous referees, participants at a seminar at the BIS, the People's Bank of China-BIS Research Conference on Globalisation and Inflation Dynamics in Asia and the Pacific, the CityU-JIMF International Conference on Pacific Rim Economies and the Evolution of the International Monetary Architecture, Eli Remolona, James Yetman, and our discussants Toshitaka Sekine and Xuan Song Tam for very helpful comments and suggestions.
} 
international competition on domestic price markups and overall wage and price setting dynamics. Most of the literature on the impact of globalisation on prices has focused on inflation in the advanced economies, treating Asian economies as a source of low-cost exports that could put downward pressure on inflation in advanced economies. Auer and Fischer (2010) and Auer et al (2013) find strong downward impacts from import competition in the emerging markets on producer prices in the United States and Europe, respectively.

A recent exception is Hirakata et al (2014), who first apply the methodology of Auer and Fischer (2010) to the case of Japan, finding that the downward effect of Chinese imports on Japanese domestic prices is even more pronounced than is the case for Chinese imports on domestic prices in the United States. Hirakata et al argue that the reason underlying this more pronounced downward effect is the composition of trade: whereas trade between China and the United States is dominated by final goods, input goods make up a substantial part of the trade between Japan and China. The authors then document theoretically how such a heterogeneous "China price" effect can arise in a dynamic stochastic general equilibrium (DSGE) model that extends Burstein et al (2008) to the three-country case. ${ }^{2}$

Greater real integration could also increase the sensitivity of inflation to cross-border shocks. The average economy is now substantially more integrated in world trade than was the case some decades ago. Worldwide, exports of goods as a share of global GDP have increased, from $17 \%$ to $25 \%$ during $1980-2012$. For 12 economies in the Asia-Pacific region, the increase has been even more prominent, with the share climbing from $15 \%$ to $26 \%$ during the same time period. ${ }^{3}$ As a result, it seems fair to argue that the average economy is now more prone to international shocks via the trade channel than before. Such an impact is in addition to the effect of globalisation on the level of inflation due to import competition.

The increased real integration in Asia is reflected especially in the region's manufacturing supply chains (see Baldwin and López-González (2013) on the global pattern of supply chain trade). In closely integrated supply chains, any shock to domestic production costs or exchange rates could be easily passed through to economies in the supply chain, affecting intermediate prices in other economies, with potential implications for headline inflation as well. ${ }^{4}$

Our analysis draws on Auer and Sauré (2014), who - building on Di Giovanni and Levchenko (2010) and Johnson (2014) - identify price spillovers via the global supply network. In contrast to Auer and Sauré (2014), who examine how intrinsic cost shocks spill over via input-output linkages and thus translate local cost shocks into a globalised inflation process, we here focus on the more narrowly defined question as to whether input-output linkages matter for the degree of exchange rate pass-through into domestic prices. While previous research has addressed a variety of issues related to international production

\footnotetext{
${ }^{2}$ Lipińska and Millard (2012) show in the context of a theoretical model how productivity increases in the developing economies could lead to higher inflation in the advanced economies, depending on oil demand elasticities and the structure of labour markets. See also Holz and Mehrotra (2013) and the discussion in BIS (2009).

3 These are the 12 BIS member economies in the Asia-Pacific region: Australia, China, Hong Kong SAR, India, Indonesia, Japan, Korea, Malaysia, New Zealand, the Philippines, Singapore and Thailand.

${ }^{4}$ In some cases, a supply chain may decrease the sensitivity of prices to exchange rate changes. If production is divided between a large number of firms located in different countries, each adding a level amount of value to the finished product, then a depreciation in the local exchange rate implies, ceteris paribus, a nearly offsetting increase in both costs and revenues. In a sticky price context, a finely divided supply chain may therefore be less sensitive to exchange rate changes.
} 
networks, such an impact of exchange rate fluctuations on domestic prices and thus inflation has not previously been analysed. ${ }^{5}$

In this study, we examine the evidence for cross-border price spillovers among economies participating in the pan-Asian supply chain. Instead of treating the Asian economies as sources of low-cost exports, we consider them importers themselves, and as such prone to cross-border shocks resulting from closer real integration. We start the analysis by studying the impact of trade linkages on the co-movement of aggregate (country-level) prices, in terms of both consumer and producer prices. However, we emphasise that a limitation with country-level data is that it is difficult to control for all the relevant factors that could possibly affect price co-movement at an aggregate level. Business cycle correlation and commonalities in monetary policy are obvious examples. In contrast, sectoral data allow us to disentangle the importance of trade integration in a relative sense - we can examine whether more integrated sectors will also experience a greater co-movement of prices.

These considerations motivate the use of sectoral data to analyse the impact of trade integration on price spillovers. In the sectoral analysis, we draw on the novel World InputOutput Database (WIOD (2012) and Timmer et al (2013a,b). This database is an extension of the national input-output tables, and was developed to analyse, inter alia, the effects of globalisation on trade patterns.

In our framework, as in Amiti et al (2014), the presence of imported intermediate goods implies that the exchange rate affects the domestic cost of production. Moreover, markups are variable, so firms may not fully pass cost shocks through to prices. In the empirical analysis, we evaluate the extent to which domestic producer prices react to changes in costs of imported intermediate inputs, the latter possibly caused by exchange rate movements. A crucial role is played by the importance of imported inputs as a fraction of a sector's total variable costs.

To preview our findings, we find that both headline inflation rates and producer prices move more closely together between those Asian economies that trade more with one another, ie that share a higher degree of trade intensity. Moreover, the impacts through higher costs of imported intermediate inputs on domestic producer prices are statistically and economically significant for economies participating in the supply chain. We show that the share of imported intermediate inputs in total variable costs is roughly $17 \%$, on average, for the seven Asia-Pacific economies for which data are available in the WIOD database. ${ }^{6}$ Moreover, for a mean importing sector in the data, when the exchange rate changes by $1 \%$, producer prices change cumulatively by close to $0.3 \%$ over the following two years. ${ }^{7}$ These results suggest that real integration through the supply chain matters for domestic price dynamics in the Asia-Pacific region.

Our paper is related to research examining the importance of real integration - or international factors more broadly - for inflation dynamics. Ciccarelli and Mojon (2010) and Mumtaz and Surico (2012) highlight the importance of an estimated global factor in accounting for the dynamics of national inflation rates. Monacelli and Sala (2009) find a

\footnotetext{
${ }^{5}$ A recent paper, IMF (2013), finds that higher economic growth is positively associated with participation in global supply chain networks.

${ }_{7}$ Australia, China, Chinese Taipei, India, Indonesia, Japan and Korea.

${ }^{7}$ Computed at the mean imported-input intensity in our sample.
} 
significant relationship at the sectoral level between the importance of the common international factor in driving prices and trade openness. Trade links are also relevant in the literature on global output gaps, whereby (trade-weighted) measures of external output gaps have been found to significantly contribute to domestic inflation equations (eg Borio and Filardo (2007); earlier work includes eg Tootell (1998)). ${ }^{8}$

Evaluation of the determinants of inflation co-movement at a country level is related to previous research on business cycle co-movement (see eg Baxter and Kouparitsas (2005) and the references therein). Finally, our research also ties in with the literature on exchange rate pass-through, in particular in an environment where intermediate inputs account for a large share of imports (eg Goldberg and Campa (2010), Amiti et al (2014) and Fauceglia et al (2013)).

However, previous evidence on the importance of the trade channel for Asian inflation dynamics is sparse. The lack of previous research is particularly evident in the case of sectoral data - but it is only at this level where the supply chain links can be effectively analysed.

This paper is structured as follows. The next section presents some stylised facts about comovement of inflation in the Asia-Pacific region and the increasing importance of intraregional trade. In Section 3, we describe our data set and the empirical framework, and present the results of the analysis of sectoral price spillovers along the supply chain. Section 4 concludes the paper.

\section{Some stylised facts}

In this section, we present some stylised facts about the co-movement of inflation in the Asia-Pacific region in the past three decades, together with the increased importance of intraregional trade. Our focus in the country-level analysis is on the 12 BIS member economies in the Asia-Pacific region: Australia, China, Hong Kong SAR, India, Indonesia, Japan, Korea, Malaysia, New Zealand, the Philippines, Singapore and Thailand. We use inflation rates at quarterly frequency given that monthly data are not available for Australia and New Zealand.

Graph 1 shows the standard deviation of economy-level inflation rates across the region, for both consumer and producer prices during 1980-2012. The further apart the inflation rates between the economies, the higher is the value shown in the graph. To remove outliers, we exclude the economies with both the lowest and highest inflation rates for each year from the construction of the standard deviation. The graph shows that the past three decades have seen a notable convergence of the levels of inflation rates in the Asia-Pacific region, especially in terms of consumer prices (left-hand panel).

Co-movement of prices in Asia ${ }^{1}$

Graph 1

Standard deviation of inflation rates across the economies ${ }^{2}$

CPI inflation $^{3} \quad$ PPI inflation ${ }^{4}$

Per cent

\footnotetext{
${ }^{8}$ Milani (2009) confirms the reduced-form evidence on the importance of global output gaps in the context of a structural model.
} 


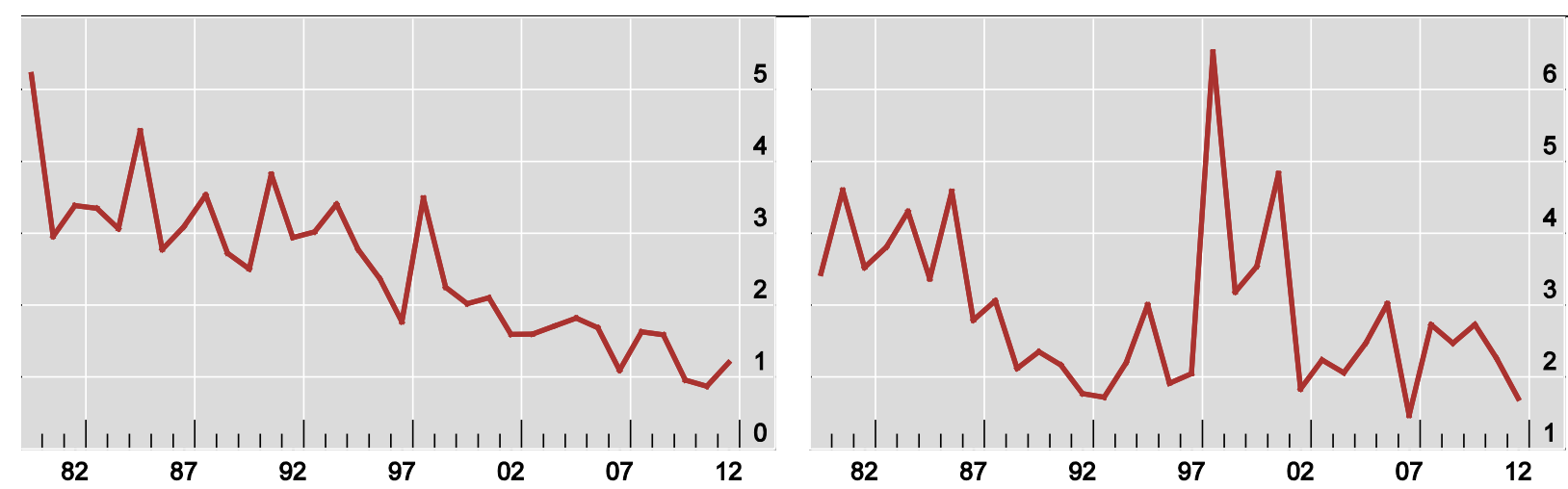

${ }^{1}$ Australia, China, Hong Kong SAR, India, Indonesia, Japan, Korea, Malaysia, New Zealand, the Philippines, Singapore and Thailand. ${ }^{2}$ Standard deviation is computed across the different economies, using the average annual inflation rate for each economy for each year; the lowest and highest inflation rates are excluded for each year. ${ }^{3}$ Wholesale prices for India. ${ }^{4}$ Where data are available.

Sources: CEIC; Datastream; national data; authors' calculations.

At the same time as inflation rates have become more similar in terms of their levels, trade between these same economies has accounted for an increasing share of their total international trade. Graph 2 shows that, for all economies except China, the share of trade with other Asian economies was larger in 2012 than in 1980. For many of them (all except China, India, Japan and Korea), the trade with our sample of Asian economies accounts for over $50 \%$ of total international trade. Part of the increase reflects the deepening of the crossborder supply chains in Asia, which we investigate formally in Section 3.

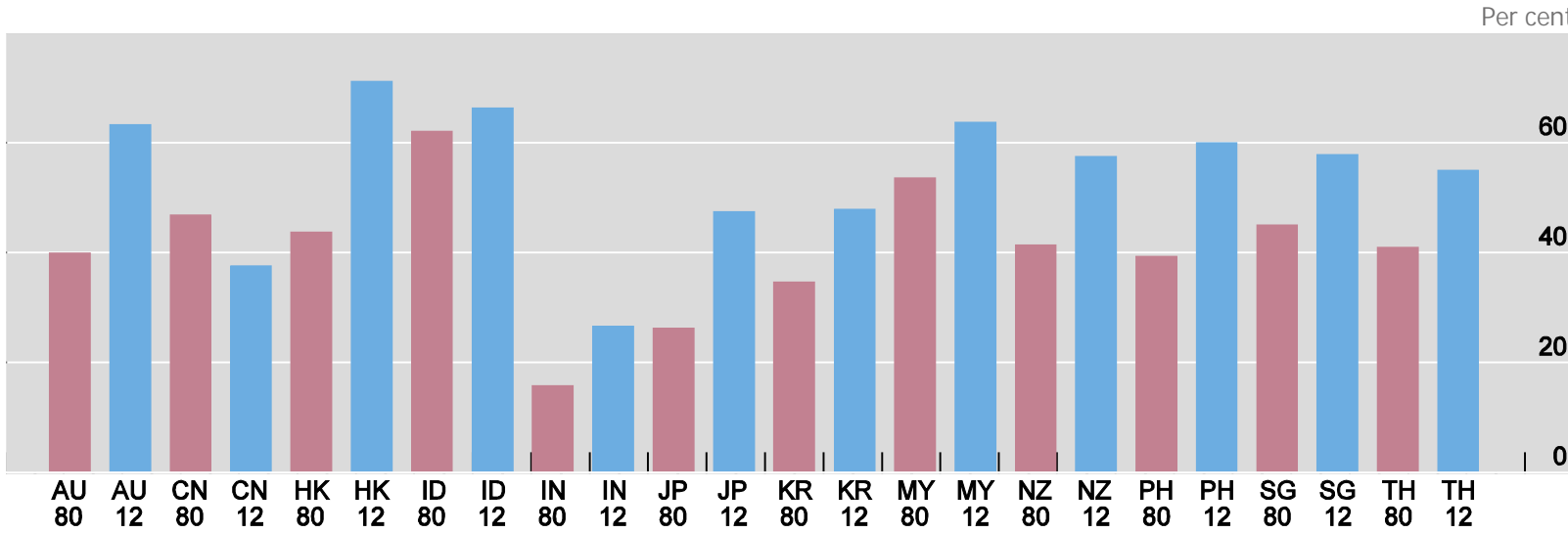

$\mathrm{AU}=$ Australia; $\mathrm{CN}=$ China; HK = Hong Kong SAR; ID = Indonesia; IN = India; JP = Japan; KR = Korea; MY = Malaysia; NZ = New Zealand; $\mathrm{PH}=$ Philippines; $\mathrm{SG}=$ Singapore; $\mathrm{TH}=$ Thailand.

1 Share of trade with Asia as a share of total international trade. Trade is the sum of exports and imports. The Asian aggregate includes Australia, China, Hong Kong SAR, India, Indonesia, Japan, Korea, Malaysia, New Zealand, the Philippines, Singapore and Thailand. For Singapore in 1980, trade with Indonesia is missing. China's exports to India in 1980 are proxied by their corresponding value in 1981.

Sources: IMF, Direction of Trade Statistics; authors' calculations.

Is there any evidence that a greater interconnectedness through trade has led to greater comovement of inflation rates at the economy-wide level? Inflation co-movement could stem from common shocks to inflation, such as productivity shocks or simultaneous changes in 
the conduct of monetary policy (see eg Henriksen et al (2008) and Rogoff (2003)). ${ }^{9}$ In the two-country open-economy New-Keynesian model by Engel (2011), home country CPI inflation is defined as the weighted average of inflation of home-produced goods and that of foreign-produced goods, with the weights determined by the utility that consumers derive from the consumption of home relative to foreign goods (a proxy for openness). Under producer currency pricing, there is a mechanical link between foreign consumer price inflation and home inflation, and this link is stronger the more open the home economy is to trade.

To examine the link between trade and inflation co-movement, we estimate a model that explicitly links the correlation between inflation rates of different economies with their bilateral trade intensities - the latter measuring how closely two economies are connected through international trade. Our approach is similar to that of Artis and Okubo (2012), who examine the impact of trade on business cycle synchronisation using a gravity-type model. The estimated equation is of the form:

$$
\begin{aligned}
& \operatorname{Corr} \_\pi_{i j t}=\alpha+\beta_{1}\left(\text { Trade }_{i j t}\right)+\beta_{2}\left(\text { Corr_mon_pol }_{i j t}\right)+\beta_{3}\left({\operatorname{Corr} \_y^{g a p}}_{i j t}\right)+\beta_{4}\left(\operatorname{Corr} \_p r o d \_g r o w t h_{i j t}\right)+ \\
& \beta_{5}\left(\text { Dummies }_{i j t}\right)+\varepsilon_{i j t}
\end{aligned}
$$

where $\operatorname{Corr}_{-} \pi_{i j}$ is the correlation of inflation rates between economies $i$ and $j$. We examine both headline (consumer price) and producer price inflation. Trade $e_{i j}$ denotes the trade intensity between the two economies, measured by export intensity. Following Artis and Okubo (2012), this is defined as:

$$
\operatorname{Trade}_{i j} \equiv \frac{X_{i j} / X_{i}}{M_{j} /\left(M^{W}-M_{i}\right)}
$$

where $X_{i}$ denotes total exports from country $i$ and $M_{i}$ is total imports into country $i . X_{i j}$ is exports from country $i$ to country $j . M^{W}$ denotes the total world imports. A higher value for this index indicates that the two economies are more closely linked by international trade. Corr_mon_pol ${ }_{i j}$ denotes the correlation between broad money growth between economies $i$ and $j$, used as a proxy for the commonality of the monetary policy stance, which is relevant due to the monetary nature of inflation in the long run. ${ }^{10} \operatorname{Corr}_{-} y^{\text {gap }}{ }_{i j}$ denotes the correlation between the output gaps of economies $i$ and $j$, capturing the co-movement of inflation that is due to business cycle co-movement. Corr_prod_growth ${ }_{i j}$ is the correlation between labour productivity growth rates, with a closer co-movement possibly reflecting common productivity

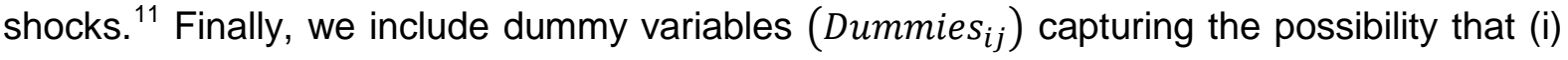
both economies are developing and (ii) both countries are industrialised, following the

\footnotetext{
${ }^{9}$ See also Binici et al (2012) on the channels through which trade openness matters for inflation.

${ }^{10}$ Ciccarelli and Mojon (2010), in the working paper version (2008) of their article, emphasise that commonalities in monetary policy could reduce the importance of the global component of inflation at business cycle frequencies. This could arise if central banks around the world follow the same reaction function and offset those inflation movements that are due to global forces, for example.

${ }^{11}$ For the estimation of (1), Corr $\pi_{i j t}$ is expressed as the correlation of inflation rates (CPI or PPI, quarterly yearon-year) during the time period considered. The trade data are the averages of annual totals for the same periods. Corr_mon_pol ${ }_{i j}$ is the correlation between broad money growth (quarterly year-on-year) in the two economies. M3 is used for Australia and Thailand, M2 for all others. The measures for the output gaps in $\operatorname{Corr}_{-} y_{i j}^{\text {gap }}{ }_{i j}$ are obtained from data on annual real GDP, using the Hodrick-Prescott filter with a conventional smoothing parameter of 100 . Labour productivity is defined as real GDP per total employment. Hong Kong SAR and Singapore are omitted from the estimation, due to the different structure of trade flows in these economies, in particular the importance of re-exports (see eg Feenstra and Hanson (2004)).
} 
classification of the IMF's World Economic Outlook. Baxter and Kouparitsas (2005) find such dummy variables to be "robust" determinants of business cycle co-movement. Such dummies could also matter for inflation co-movement, if we assume that countries with similar levels of economic development are affected in comparable ways by external shocks.

The time dimension of the panel is comprised of three observations: 1980-89, 1990-99 and 2000-12. The exact starting date depends on data availability for each economy pair (see Appendix for details). Over these three time periods, the average CPI correlation in our sample is 0.32 and the average PPI correlation is 0.39 ; the standard deviations of these same correlations are 0.32 and 0.37 , respectively. The right-hand side variables are normalised by dividing them by their standard deviation. 


\begin{tabular}{|c|c|c|c|c|c|c|c|c|c|c|}
\hline \multicolumn{10}{|c|}{ Inflation co-movement and trade intensity } & \multirow{2}{*}{$\begin{array}{l}\text { Table } 1 \\
(10)\end{array}$} \\
\hline Model & $(1)$ & (2) & (3) & (4) & (5) & (6) & (7) & (8) & (9) & \\
\hline Price & $\mathrm{CPI}$ & $\mathrm{CPI}$ & $\mathrm{CPI}$ & $\mathrm{CPI}$ & $\mathrm{CPI}$ & $\mathrm{PPI}$ & $\mathrm{PPI}$ & PPI & PPI & PPI \\
\hline Trade intensity & $\begin{array}{l}0.056 * * * \\
(0.010)\end{array}$ & $\begin{array}{l}0.057 * * * \\
(0.010)\end{array}$ & $\begin{array}{l}0.052 * * * \\
(0.010)\end{array}$ & $\begin{array}{l}0.035 * * * \\
(0.012)\end{array}$ & $\begin{array}{l}0.031^{* *} \\
(0.013)\end{array}$ & $\begin{array}{l}0.063 * * * \\
(0.013)\end{array}$ & $\begin{array}{l}0.062 * * * \\
(0.013)\end{array}$ & $\begin{array}{l}0.059 * * * \\
(0.013)\end{array}$ & $\begin{array}{l}0.052^{* * *} \\
(0.011)\end{array}$ & $\begin{array}{l}0.036 * * * \\
(0.012)\end{array}$ \\
\hline $\begin{array}{l}\text { Correlation of broad } \\
\text { money growth }\end{array}$ & & $\begin{array}{l}-0.008 \\
(0.024)\end{array}$ & $\begin{array}{l}-0.009 \\
(0.025)\end{array}$ & $\begin{array}{l}-0.013 \\
(0.029)\end{array}$ & $\begin{array}{l}-0.012 \\
(0.028)\end{array}$ & & $\begin{array}{c}0.007 \\
(0.027)\end{array}$ & $\begin{array}{c}0.007 \\
(0.027)\end{array}$ & $\begin{array}{c}0.017 \\
(0.027)\end{array}$ & $\begin{array}{r}0.015 \\
(0.027)\end{array}$ \\
\hline $\begin{array}{l}\text { Correlation of output } \\
\text { gaps }\end{array}$ & & & $\begin{array}{l}0.069 * * * \\
(0.024)\end{array}$ & $\begin{array}{c}0.008 \\
(0.026)\end{array}$ & $\begin{array}{r}0.005 \\
(0.025)\end{array}$ & & & $\begin{array}{c}0.039 \\
(0.025)\end{array}$ & $\begin{array}{l}-0.020 \\
(0.021)\end{array}$ & $\begin{array}{l}-0.026 \\
(0.021)\end{array}$ \\
\hline $\begin{array}{l}\text { Correlation of } \\
\text { productivity growth }\end{array}$ & & & & $\begin{array}{l}0.084 * * * \\
(0.026)\end{array}$ & $\begin{array}{l}0.085 * * * \\
(0.026)\end{array}$ & & & & $\begin{array}{l}0.069 * * * \\
(0.024)\end{array}$ & $\begin{array}{l}0.074 * * * \\
(0.023)\end{array}$ \\
\hline $\begin{array}{l}\text { Both industrialised } \\
\text { economies }\end{array}$ & & & & & $\begin{array}{c}0.054 \\
(0.047)\end{array}$ & & & & & $\begin{array}{l}0.141^{* * *} \\
(0.038)\end{array}$ \\
\hline $\begin{array}{l}\text { Both developing } \\
\text { economies }\end{array}$ & & & & & $\begin{array}{c}0.036 \\
(0.055)\end{array}$ & & & & & $\begin{array}{c}0.034 \\
(0.054)\end{array}$ \\
\hline $\mathrm{N}$ & 210 & 210 & 210 & 200 & 200 & 200 & 200 & 200 & 192 & 192 \\
\hline Adjusted $\mathrm{R}^{2}$ & 0.068 & 0.064 & 0.102 & 0.103 & 0.097 & 0.266 & 0.263 & 0.270 & 0.304 & 0.308 \\
\hline
\end{tabular}

Dependent variable is the correlation of inflation rates (CPI or PPI). *, ** and ${ }^{* * *}$ denote statistical significance at the $10 \%, 5 \%$ and $1 \%$ levels, respectively. Estimated with period fixed effects. White robust standard errors in parentheses. Excluding Hong Kong SAR and Singapore. Coefficients are normalised by dividing variables by their standard deviation. 
Table 1 shows that there is a positive and statistically significant correlation between the comovement of inflation rates (both $\mathrm{CPI}$ and PPI) and trade intensity for our sample of Asian economies. Regarding the magnitude of the estimated coefficients, specifications (1) to (5) suggest that a one standard deviation increase in trade intensity between two economies is associated with a 3-6 percentage point increase in the correlation between the CPI inflation rates of the same economies. Similarly, a rise in trade intensity of the same size leads to a roughly 4-6 percentage point increase in the correlation between the PPI inflation rates of the same economies, as shown in specifications (6) to (10). The statistical significance of the trade intensity variable remains robust to the inclusion of our control variables, suggesting that more highly correlated inflation rates are not driven solely by commonality of monetary policy, business cycles, productivity shocks or the type of economies (industrialised/developing).

It may appear surprising that even as consumer prices are affected by distribution costs and other non-tradable components, the point estimate on the trade intensity variable is only slightly higher when producer prices are used, with no statistically significant difference between the coefficients. However, as argued by Goldberg and Campa (2010), when imported inputs are used in the production of non-tradables, the sensitivity of consumer prices to exchange rate movements is enhanced. We also note that the goodness of fit of the model with producer prices is markedly higher than the one with consumer prices, as shown in the last row of Table 1.

These results should only be taken as suggestive. Reverse causality cannot be ruled out in the econometric specification, and factors other than those included on the right-hand side may lead to a closer co-movement of inflation rates. Indeed, the adjusted $\mathrm{R}^{2}$ values suggest that some, but clearly not all, of the variation in inflation co-movement is captured by our model. For these reasons, the use of sectoral data has benefits. It allows us to disentangle the impact of real integration in a relative sense - sectors that are more closely connected between different economies are also more likely to experience greater cross-border price spillovers, controlling for country-specific or common trends across time. The next sections use sectoral data that reflect variation in the Asian supply chain to investigate the link between real integration and price spillovers.

\section{Supply chain links and price spillovers into Asia-Pacific}

\subsection{Details about the data}

We use data from the World Input-Output Database (WIOD henceforth) to illustrate the supply chain dynamics and measure price spillovers within the Asia-Pacific region. The WIOD has been developed, among other objectives, to aid the analysis of the effects of globalisation on trade patterns (WIOD (2012)). The world input-output table is basically an extension of the national input-output tables. The national tables specify, for each industry, the use of the product, being for either industry (intermediate) or final use. Final use includes domestic final use (private consumption, government consumption, investment) and exports. Importantly for our analysis, the world input-output table additionally shows in which foreign 
industry the product was produced, and how the exports of a country are used, by which foreign industry or final user. ${ }^{12}$

The WIOD covers $27 \mathrm{EU}$ countries and 13 other major economies, for 1995-2009. We focus our analysis on data from the Asia-Pacific region, ie Australia, China, Chinese Taipei, India, Indonesia, Japan and Korea, with all the WIOD's 40 economies included as trading partners in the analysis. Table 2 shows the economies included in the database.

Economies included in the World Input-Output Database

\begin{tabular}{lclll}
\hline & European Union & & North and Latin America & Asia-Pacific \\
\hline Austria & Germany & Netherlands & Canada & Australia \\
Belgium & Greece & Poland & United States & China \\
Bulgaria & Hungary & Portugal & Brazil & Chinese Taipei \\
Cyprus & Ireland & Romania & Mexico & India \\
Czech Republic & Italy & Slovakia & & Indonesia \\
Denmark & Latvia & Slovenia & & Other \\
\cline { 2 - 4 } Estonia & Lithuania & Spain & Russia & Korea \\
Finland & Luxembourg & Sweden & Turkey & \\
France & Malta & United & & \\
& & Kingdom & & \\
\hline
\end{tabular}

The regional classification in this study has been adapted to more closely match the BIS definition of regions.

Differences in the intensity of import use across sectors play a crucial role in our analysis. Using data from the WIOD, we specify the intensity of import use as the share of intermediate imports in total output. We further assume that variable costs account for $70 \%$ of total costs, and proxy the latter by the value of total output. The cost share of imported intermediate inputs is then equal to the share of imported intermediate inputs in total variable costs.

How has the cost share of imported inputs changed over time in the Asia-Pacific economies? Graph 3 (left-hand panel) shows that, pooling the seven economies together, the cost share of imported inputs increased from roughly $14 \%$ in 1995 to $16 \%$ in 2000 . This was followed by a rapid increase in the cost share from 2003 to 2008, reaching a level close to $20 \%$, before global trade collapsed at the time of the international financial crisis. The right-hand panel shows how the cost share has evolved in the different economies. In all other economies except Indonesia, the cost share of imported inputs was higher in 2008 than in 1998. In Chinese Taipei, the cost share was close to $35 \%$ in 2008. Perhaps surprisingly, given the importance of mainland China in the global supply chains, the imported input cost share in China in 2008 was lower than in the other economies, with the

\footnotetext{
${ }^{12}$ We note that there exists a second data set on international input output linkages, the "Statistics on Trade in Value Added" (TiVA) database compiled by the OECD and the WTO. The TiVA database does not include information on bilateral industry-specific input use. For example, the WIOD includes information on the value of imports used by the German car industry that are produced by the Japanese steel industry. In the TiVA database, such information exists only in imputed form. To properly calculate the change in the effective cost of the bundle of imported inputs used by each country, we need to know the origin distribution of these inputs. Therefore, we use the WIOD database in our analysis.
} 
exception of Japan. Nonetheless, the increase in the imported input cost share from 1998 to 2008 in China was particularly prominent, doubling during this 10 -year period.

\section{Cost share of imported inputs}

Average imported input cost share, seven economies pooled

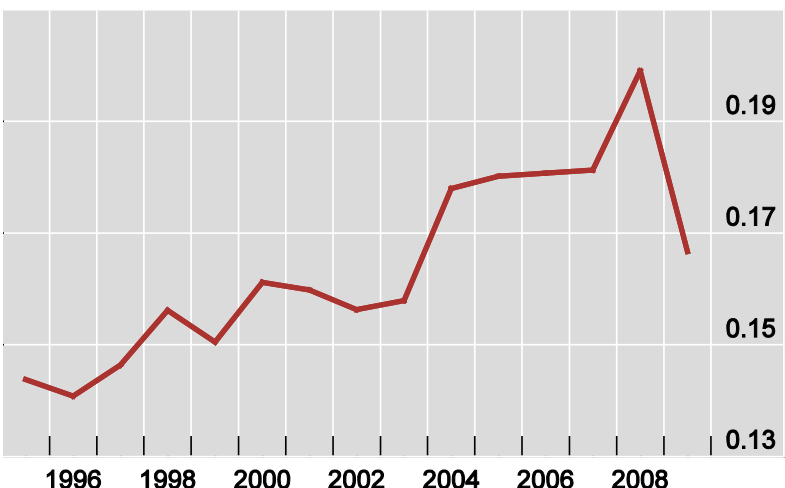

Average imported input cost share, 1998 and 2008

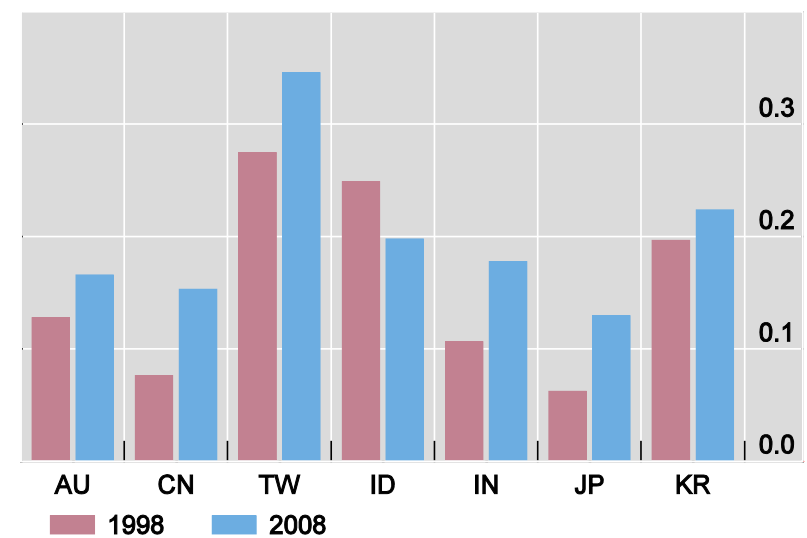

$\mathrm{AU}=$ Australia; $\mathrm{CN}=$ China; ID = Indonesia; IN = India; JP = Japan; KR = Korea; TW = Chinese Taipei.

Source: Authors' calculations based on WIOD (2012).

For this group of seven Asia-Pacific economies, Graph 4 displays the sectoral imported input cost shares in 2008. The sectors follow the NACE classification. For the textiles sector, the cost share is $16 \%$, and it exceeds $20 \%$ for the manufacturing of machinery and equipment, for example. A particularly high cost share, $55 \%$, is recorded for the "coke, refined petroleum products and nuclear fuel" sector.

Seven Asia-Pacific economies pooled

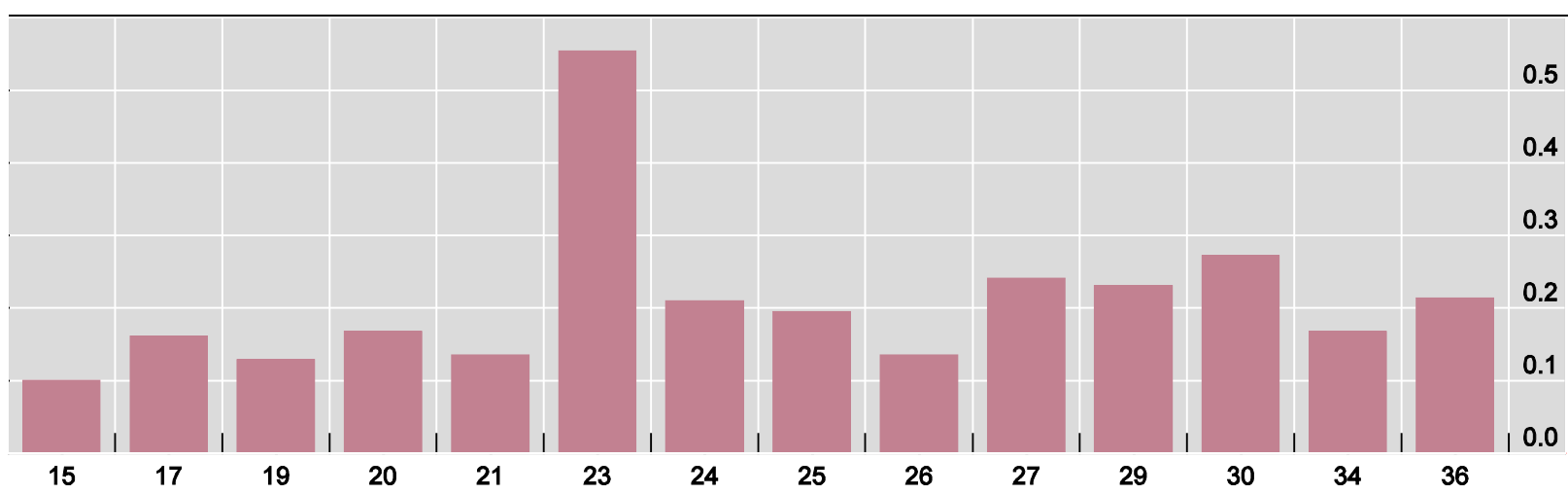

$15=$ food products and beverages; $17=$ textiles; $19=$ leather and leather products; $20=$ wood and wood products; $21=$ pulp, paper and paper products; $23=$ coke, refined petroleum products and nuclear fuel; $24=$ chemicals and chemical products; $25=$ rubber and plastic products; $26=$ other non-metallic mineral products; 27 = basic metals; $29=$ machinery and equipment n.e.c.; $30=$ office machinery and computers; $34=$ motor vehicles, trailers and semi-trailers; 36 = furniture, manufacturing n.e.c.

Source: Authors' calculations based on WIOD (2012). 


\subsection{Framework relating import prices to production costs}

In the presence of imported intermediate goods, fluctuations in the prices of imports that are themselves driven by exchange rate movements affect the domestic cost of production and, ultimately, the prices that domestic producers and exporters charge (eg Amiti et al (2014)). We next lay down a parsimonious model to describe these relations, motivating our following empirical analysis.

Denoting the domestic price that firm $n$ charges for its good by $p_{n, t}^{D}$, the marginal cost of producing one unit of this good by $c_{n, t}^{D}$, and the markup of firm $n$ by $\pi_{n, t}^{D}$, it holds that

$$
p_{n, t}^{D}=\pi_{n, t}^{D} * c_{n, t}^{D}
$$

The markup $\pi_{n, t}^{D}$ itself is a function that depends on, among other things, the per-unit cost of the firm. Denoting percentage changes of any variable by a hat, it then follows that

$$
\hat{p}_{n, t}^{D}=\hat{\pi}_{n, t}^{D}+\hat{c}_{n, t}^{D}=\left(\frac{\partial \pi_{n, t}^{D}}{\partial c_{n, t}^{D}} \frac{c_{n, t}^{D}}{\pi_{n, t}^{D}}+1\right) \hat{c}_{n, t}^{D}+\hat{\epsilon}_{n, t}^{\pi}
$$

ie the percentage change in the firm's price is equal to the change in its markup and the change in its costs. Since the markup itself is a function of marginal costs, the change in the price is then equal to $\frac{\partial \pi_{n, t}^{D}}{\partial c_{n, t}^{D}} \frac{c_{n, t}^{D}}{\pi_{n, t}^{D}}+1$ multiplied by any cost change plus $\hat{\epsilon}_{n, t}^{\pi}$, which captures other fluctuations in markups that are uncorrelated with cost changes.

Costs are composed of local costs that are paid in local currencies $\left(c_{n, t}^{L}\right.$, equal to the cost per unit $p_{n, t}^{L}$ multiplied by the quantity consumed $q_{n, t}^{L}$ ) and imported intermediate inputs $\left(c_{n, t}^{I}\right.$, equal to the cost per unit $p_{n, t}^{I}$ multiplied by the quantity consumed $\left.q_{n, t}^{I}\right)$ :

$$
c_{n, t}^{D}=c_{n, t}^{I}+c_{n, t}^{L}=p_{n, t}^{I} * q_{n, t}^{I}+p_{n, t}^{L} * q_{n, t}^{L}
$$

If the input quantities do not change, and allowing for firm-specific cost shocks $\hat{\epsilon}_{n, t}^{C}$, we have

$$
\hat{c}_{n, t}^{D}=\theta_{n, t}^{I} * \hat{p}_{n, t}^{I}+\left(1-\theta_{n, t}^{I}\right) * \hat{p}_{n, t}^{L}+\hat{\epsilon}_{n, t}^{C}
$$

where $\theta_{n, t}^{I}$ is the imported input cost share equal to $\frac{c_{n, t}^{I}}{c_{n, t}^{I}+c_{n, t}^{L}}$. It thus holds that

$$
\hat{p}_{n, t}^{D}=\left(\frac{\partial \pi_{n, t}^{D}}{\partial c_{n, t}^{D}} \frac{c_{n, t}^{D}}{\pi_{n, t}^{D}}+1\right) \theta_{n, t}^{I} * \hat{p}_{n, t}^{I}+\left(\frac{\partial \pi_{n, t}^{D}}{\partial c_{n, t}^{D}} \frac{c_{n, t}^{D}}{\pi_{n, t}^{D}}+1\right)\left(1-\theta_{n, t}^{I}\right) * \hat{p}_{n, t}^{L}+\hat{\epsilon}_{n, t}
$$

We observe changes in both traded and non-traded input costs and $\theta_{n, t}^{I}$ in our data. We thus estimate markup elasticities in the data. Amiti et al (2012) derive a theoretical measure of how the firm-specific markup evolves in the presence of imported input use and pricing to market.

Before presenting the estimation results, we describe the construction of the IIPI, the import price index that is denoted by $\hat{p}_{n, t}^{I}$ above. Each importing industry uses inputs from a variety of other sectors. We thus construct a sector's IIPI as the weighted average of all import price indices $(I P I)$ of country $c$ using the relative importance of imported inputs from sector $k$ as a fraction of all inputs used by sector $s$ as weights. That is, we construct: 


$$
\widehat{I P} I_{c, s, t}^{I}=\frac{\text { Inputs }_{c, s, k, t}}{\sum_{k \in S} \operatorname{Inputs}_{c, s, k, t}} \widehat{I P I} I_{c, k, t}^{I}
$$

where $k$ denotes the sector supplying the inputs and $s$ the sector using them.

\subsection{Results}

In the following, we examine the extent to which domestic producer prices react to changes in imported input costs. A crucial role is played by the importance of imported inputs as a fraction of a sector's total variable costs. In all specifications of the upper panel of Table 3, the dependent variable is defined as the monthly change in the (log of the) sectoral producer price index of the importer. All models include sector fixed effects to capture any crosssectoral trends, such as structural transformation, that could have occurred during the sample period.

Specification (1) in Table 3 documents that, on average, domestic prices are positively correlated with the import price index. In this most parsimonious specification, the only independent variable is the change in the imported intermediate goods price index, IIPI. The coefficient is estimated at 0.21 , which if interpreted causally would imply that a $1 \%$ increase in the imported intermediate goods price index is associated with a $0.21 \%$ increase in domestic producer prices.

Specification (2) documents that the imported intermediate goods price index is more correlated with domestic prices in sectors and economies that more intensively use imported intermediate inputs. This specification adds the interaction of the change in the sectoral import price index with the sector importer-specific cost share. The estimated specification is of the form:

$$
\hat{p}_{s, t, t-1}^{D}=k_{s}^{D}+\alpha I \widehat{I P} I_{s, t, t-1}+\beta \theta_{s, t}^{I} I \widehat{I P} I_{s, t, t-1}+\gamma \theta_{s, t}^{I}+\hat{\epsilon}_{s, t}
$$

The interaction coefficient, $\beta$, is estimated to be 0.34 , while the main effect, $\alpha$, is 0.13 . As we include an interaction variable, $\theta_{s, t}^{I}$ must also be included directly. We note that, because of the inclusion of fixed effects, $\gamma$ captures the impact of changes in imported input intensity on prices rather than the level.

To gauge the magnitude of the uncovered effect in specification (2), consider two sectors with input intensities of 0.04 and 0.49 , respectively. Such intensities correspond to the 5th and 95th percentiles of the imported intermediate input cost share in our sample. For the sector that uses fewer imported intermediate inputs, a 1\% increase in IIPI is associated with a $0.14 \%$ increase in domestic producer prices $(0.14 \%=0.13 \%+0.04 * 0.34 \%)$. In contrast, the same $1 \%$ increase in IIPI is associated with a $0.30 \%$ increase in domestic producer prices when half the sector's costs stem from imported intermediate inputs $(0.30 \%=0.13 \%$ $+0.49 * 0.34 \%$ ). The spillover rate into domestic prices is thus well over twice as large in the sector that uses imports more intensively. 
Estimation results, spillovers to producer prices from imported inputs

Table 3

\begin{tabular}{|c|c|c|c|c|c|}
\hline \multirow[t]{2}{*}{ Panel A } & $(1)$ & $(2)$ & & (3) & $(4)$ \\
\hline & \multicolumn{5}{|c|}{ Dependent variable is monthly \% change in sectoral PPI } \\
\hline \multirow[t]{2}{*}{$\Delta$ Importer IIPI } & $0.211^{* *}$ & 0.128 & & $0.160 * * *$ & \\
\hline & $(0.081)$ & $(0.087)$ & & $(0.058)$ & \\
\hline \multirow{2}{*}{$\begin{array}{l}\Delta \text { Trade-weighted exchange } \\
\text { rate (sector-specific weights) }\end{array}$} & & & & & -0.046 \\
\hline & & & & & $(0.029)$ \\
\hline \multirow{2}{*}{$\begin{array}{l}\text { Cost change from IIPI = } \\
\Delta \mathrm{IIPI} * \text { cost share }\end{array}$} & & $0.342 * *$ & & $0.673^{* * *}$ & \\
\hline & & $(0.116)$ & & $(0.209)$ & \\
\hline \multirow{2}{*}{$\begin{array}{l}\text { Cost change from exchange } \\
\text { rate }=\Delta \text { exr } * \text { cost share }\end{array}$} & & & & & $0.198 * *$ \\
\hline & & & & & $(0.068)$ \\
\hline \multirow[t]{2}{*}{ Imported input cost share } & & 0.013 & & $0.022 * *$ & $0.022 *$ \\
\hline & & $(0.010)$ & & $(0.011)$ & $(0.011)$ \\
\hline Observations & 5,996 & 5,996 & & 5,996 & 5,996 \\
\hline $\mathrm{R}^{2}$ & 0.055 & 0.061 & & & 0.002 \\
\hline Number of panelvar & 40 & 40 & & 40 & 40 \\
\hline \multirow[t]{2}{*}{ Panel B } & & & (3.1) & $(3.2)$ & \\
\hline & & & $\Delta \mathrm{IIPI}$ & $\begin{array}{c}\Delta \mathrm{IIPI} * \\
\text { cost share }\end{array}$ & \\
\hline \multirow{2}{*}{$\begin{array}{l}\Delta \text { Trade-weighted exchange } \\
\text { rate (sector-specific weights) }\end{array}$} & & & $0.275^{* * *}$ & -0.003 & \\
\hline & & & $(0.037)$ & $(0.007)$ & \\
\hline \multirow{2}{*}{$\begin{array}{l}\text { Cost change from exchange } \\
\text { rate }=\Delta \text { exr } * \text { cost share }\end{array}$} & & & 0.032 & $0.302^{* * *}$ & \\
\hline & & & $(0.086)$ & $(0.018)$ & \\
\hline \multirow[t]{2}{*}{ Imported input cost share } & & & $0.029 *$ & $0.007^{* * *}$ & \\
\hline & & & $(0.015)$ & $(0.002)$ & \\
\hline \multicolumn{2}{|l|}{ Observations } & & 5,996 & 5,996 & \\
\hline \multicolumn{2}{|l|}{$\mathrm{R}^{2}$} & & 0.108 & 0.085 & \\
\hline \multicolumn{2}{|l|}{ Number of panelvar } & & 40 & 40 & \\
\hline
\end{tabular}

Panel A: dependent variable is the change in the importer's PPI. Panel B: first-stage regressions: dependent variables are the change in the importer's IIPI and the cost change from the IIPI, respectively. $\Delta$ is a first-difference operator. Dummy variable estimates not shown. Heteroscedasticity-robust standard errors clustered by industry are reported in parentheses below the coefficient estimates. $* * * p<0.01$, $* * p<0.05, * p<0.1$.

Specification (3) uses exchange rate movements as drivers of the IIPI, thereby addressing the problem that import prices and domestic prices might co-react to common cost shocks. This specification presents the results of a two-stage least squares estimation relating first the exchange rate to changes in the IIPI and then the projected changes in the IIPI on changes in domestic prices. Because we want to instrument both for the change in the IIPI and for the interaction of the IIPI with the imported intermediate cost share, we instrument with the exchange rate, as well as with the exchange rate interacted by the imported intermediate cost share. The exchange rate is specified as units of domestic currency per unit of foreign currency, so that an increase denotes a depreciation of the importer's currency.

Panel B presents the two first-stage estimations for the two endogenous variables, the change in the IIPI and the latter interacted with the imported intermediate cost share. In 
specification (3.1), the dependent variable is the change in the IIPI. The independent variables include the change in the trade-weighted exchange rate (exr), the imported intermediate cost share and the interaction between the two. As expected, the change in the IIPI is strongly correlated with the exchange rate, while the interaction of the exchange rate with the imported intermediate cost share has no explanatory power. Indeed, there are arguably no a priori reasons to believe that the sensitivity of the import price index itself to the exchange rate depends on the cost share of imports.

In specification (3.2), the dependent variable is the change in the IIPI interacted with the imported intermediate cost share. The independent variables are the same as in (3.1). In this first-stage estimation, the interaction of the exchange rate with the imported input cost share is strongly correlated with the dependent variable, while the exchange rate itself has no explanatory power. ${ }^{13}$

The results from the second stage estimation are presented in Panel $A$. These reveal a negative coefficient for the main effect $(-0.16)$ and a positive interaction coefficient of 0.67 , both with high statistical significance. Repeating the previous back of the envelope example for the two sectors at 5th and 95th percentiles of imported input intensity; a 1\% increase in the IIPI is now associated with a $0.13 \%$ decrease in domestic prices in the low importintensive sector $\left(-0.13 \%=-0.16 \%+0.04^{*} 0.67 \%\right)$. And, a $1 \%$ increase in the IIPI is associated with a $0.17 \%$ increase in domestic prices in the sector that intensively uses imported inputs $\left(0.17 \%=-0.16 \%+0.49^{\star} 0.67 \%\right)$.

How should one interpret the sizeable differences between specifications (3) and (2)? They probably reflect the fact that import prices and producer prices react to the same, possibly global, shocks. We thus continue to instrument for changes in the IIPI with the exchange rate in the remainder of the analysis. But instead of following the approach in (3), we present reduced-form estimations as in (4), where the independent variables are the exchange rate, the imported intermediate cost share, and the exchange rate interacted with the cost share. These estimates capture the implicit notion that the exchange rate drives changes in import prices, while these import prices affect domestic prices - especially so in sectors that intensively use imported inputs.

Importantly, using the reduced-form approach allows us to extend the sample. In some countries, sector-specific import price indices are not published, while sector-specific producer prices are available (China, India). For the other five economies (Australia, Chinese Taipei, Indonesia, Japan and Korea), data on the PPI are available for a longer time period than the IIPI.

Our baseline model, using the reduced form approach, is shown as specification (5) in Table 4. This is basically a re-estimation of (4) in the previous table, but including all country sector combinations for which a PPI is available. This increases the sample from 40 to 89 country sector combinations and from 5,996 to 11,990 monthly observations. In our baseline estimation, the exchange rate itself is not statistically significant. However, the interaction of the exchange rate with the imported input cost share is highly statistically significant and has an economically sizeable coefficient of 0.16 .

\footnotetext{
${ }^{13}$ The fact that each of the two endogenous variables is correlated with a different instrument implies that the second-stage estimation is well identified: the Cragg-Donald Wald F-statistic is 249, far exceeding the $10 \%$ critical value of 7.03 (10\% is the lowest critical value calculated for this specification by Stock and Yogo (2005)).
} 
An obvious question is how robust the results are to the inclusion of various control variables or economy and time-specific trends. As will be shown in specifications (6) to (13), an important role is played by the intensity with which the different sectors use imported inputs. This variation is mostly cross-sectional (ie cross-industry and cross-country), so our findings are not driven by aggregate patterns.

Estimation results, baseline reduced-form model and additional controls

Table 4

(5)

(6)

(7)

(8)

(9)

(10)

Dependent variable is monthly \% change in sectoral PPI

\begin{tabular}{|c|c|c|c|c|c|c|}
\hline $\begin{array}{l}\text { Trade-weighted exchange rate } \\
\text { change (sector-specific weights) }\end{array}$ & $\begin{array}{l}-0.014 \\
(0.017)\end{array}$ & $\begin{array}{l}-0.022 \\
(0.017)\end{array}$ & $\begin{array}{l}-0.014 \\
(0.017)\end{array}$ & $\begin{array}{l}-0.014 \\
(0.017)\end{array}$ & $\begin{array}{l}-0.015 \\
(0.018)\end{array}$ & $\begin{array}{l}-0.021 \\
(0.018)\end{array}$ \\
\hline $\begin{array}{l}\text { Cost change from exchange rate } \\
=\Delta \text { exr } * \text { cost share }\end{array}$ & $\begin{array}{c}0.157^{* * *} \\
(0.043)\end{array}$ & $\begin{array}{c}0.165^{* * *} \\
(0.043)\end{array}$ & $\begin{array}{c}0.155^{* * *} \\
(0.042)\end{array}$ & $\begin{array}{c}0.154^{* * *} \\
(0.042)\end{array}$ & $\begin{array}{c}0.149 * * * \\
(0.046)\end{array}$ & $\begin{array}{r}0.157^{* * *} \\
(0.042)\end{array}$ \\
\hline Imported input cost share & $\begin{array}{r}0.012 \\
(0.007)\end{array}$ & $\begin{array}{r}0.008 \\
(0.006)\end{array}$ & $\begin{array}{r}0.015^{*} \\
(0.007)\end{array}$ & $\begin{array}{r}0.015^{*} \\
(0.007)\end{array}$ & $\begin{array}{r}0.012 \\
(0.008)\end{array}$ & $\begin{array}{r}0.012 \\
(0.007)\end{array}$ \\
\hline $\begin{array}{l}\text { Change in importing country's } \\
\text { seasonally adjusted CPI }\end{array}$ & & $\begin{array}{c}0.683^{* * *} \\
(0.150)\end{array}$ & & & & $\begin{array}{r}0.585^{* * *} \\
(0.154)\end{array}$ \\
\hline Change in commodity price index & & & $\begin{array}{l}0.036 * * \\
(0.012)\end{array}$ & & & $\begin{array}{l}0.047^{* *} \\
(0.018)\end{array}$ \\
\hline $\begin{array}{l}\text { Change in energy subcomponent } \\
\text { of commodity prices }\end{array}$ & & & & $\begin{array}{l}0.025^{* *} \\
(0.009)\end{array}$ & & $\begin{array}{l}-0.013 \\
(0.011)\end{array}$ \\
\hline $\begin{array}{l}\text { Dummies for financial crises } \\
\text { (contemp \& } 12 \text { lags) }\end{array}$ & & & & & $\begin{array}{r}0.001 \\
(0.001)\end{array}$ & $\begin{array}{c}0.003^{* * *} \\
(0.001)\end{array}$ \\
\hline Observations & 11,990 & 11,990 & 11,990 & 11,990 & 11,462 & 11,462 \\
\hline$R^{2}$ & 0.002 & 0.015 & 0.012 & 0.011 & 0.004 & 0.025 \\
\hline Number of panelvar & 89 & 89 & 89 & 89 & 89 & 89 \\
\hline
\end{tabular}

Dependent variable is the change in the importer's PPI. Heteroscedasticity-robust standard errors clustered by industry are reported in parentheses below the coefficient estimates. ${ }^{* * *} p<0.01,{ }^{* *} p<0.05, * p<0.1$.

Specification (6) adds the importer's CPI inflation rate as a control variable, to capture the possibility that economy-wide demand pressures could correlate with the increase in producer prices. While this variable enters the specification with a statistically significant coefficient, the interaction variable between the exchange rate and the input cost share remains statistically significant.

Another concern with the presented estimations could be that large swings in global commodity prices - and, in particular, swings in energy prices - are driving these patterns. In specification (7) in Table 4, we thus include the change in the Goldman Sachs Commodity Index as a control. The latter is a composite index of the commodity sector, with the weight of each commodity being proportional to the value of global consumption of the commodity. Therefore, this index is a relevant metric of how commodity price developments affect national price dynamics. In specification (7), the variable indeed enters the estimation with a positive and significant coefficient. However, controlling for commodity prices has only a minimal impact on the coefficient of interest to us, the one of the cost change of imported inputs. 
Also controlling only for energy prices that might be especially important for domestic producer price dynamics does not impact the results. In specification (8) in Table 4, we control for the energy subcomponent of the Goldman Sachs Commodity Index. While this subindex too affects prices significantly, addition of this variable has no impact on the other coefficient estimates in the regression.

The presented results are also not driven by large common events such as the Asian financial crisis. In specification (9), we add as a regressor a dummy variable that is equal to one during times of financial crisis, where we use information from the database of the occurrence of financial crises in Laeven and Valencia (2012) to construct the dummy. The latter enters the specification insignificantly.

In specification (10), we document that imported input price changes do significantly affect domestic prices also conditional on controlling jointly for domestic CPI inflation, commodity price fluctuations, energy price fluctuations and the occurrence of financial crises.

Estimation results, additional time fixed effects

Dependent variable is monthly \% change in sectoral PPI

\begin{tabular}{lcccc}
\hline $\begin{array}{l}\text { Trade-weighted exchange rate } \\
\text { change (sector-specific weights) }\end{array}$ & -0.004 & -0.009 & -0.004 & -0.011 \\
\hline Cost change from exchange rate & $(0.016)$ & $(0.017)$ & $(0.017)$ & $(0.017)$ \\
$=\Delta$ exr * cost share & $0.131^{* * *}$ & $0.169 * * *$ & $0.137 * * *$ & $0.132^{* *}$ \\
\hline Imported input cost share & $(0.041)$ & $(0.046)$ & $(0.039)$ & $(0.048)$ \\
& 0.005 & 0.001 & 0.005 & 0.290 \\
Six-month change in importer & $(0.007)$ & $(0.006)$ & $(0.007)$ & $0.080^{* *}$ \\
exchange rate & & & & $0.029)$ \\
\hline Six-month cost change from & & & & $0.609 * * *$ \\
exchange rate $=\Delta$ exr $*$ cost share & & & & $(0.115)$ \\
\hline Additional time fixed effects & T-FE & T-FE by country & T-FE by industry & T-FE \\
\hline Observations & 11,990 & 11,990 & 11,990 & 11,750 \\
\hline $\mathrm{R}^{2}$ & 0.064 & 0.118 & 0.074 & 0.090 \\
\hline Number of panelvar & 89 & 89 & 89 & 89 \\
\hline
\end{tabular}

Dependent variable is the change in the importer's PPI. Specification (11) includes time fixed effects; (12) includes country time fixed effects; (13) includes industry time fixed effects. Dummy variable estimates not shown. Heteroscedasticity-robust standard errors clustered by industry are reported in parentheses below the coefficient estimates. ${ }^{* * *} p<0.01, * * p<0.05, * p<0.1$.

Other economy- or time-specific trends not explicitly considered above could also be relevant. To control for these, specifications (11) to (13) add different sets of time fixed effects to the estimation. In particular, in (11), we add time (month) fixed effects to capture general trends. In (12), we include country time fixed effects in order to absorb all variation in the data that is common within a country. Finally, specification (13) adds industry time fixed effects that absorb all variation across sectors.

The results in Table 5 show that our results are not driven by aggregate common trends across the economies (11), nor any other country-specific patterns (12). Finally, the results are not driven by sector-specific fluctuations (13). 
We note that all the models discussed so far relate monthly changes in import prices to contemporary changes in domestic producer prices. In the presence of nominal price stickiness of any sort, it is likely that changes in the costs of imported intermediate goods affect the prices that domestic producers charge only with a lag. In equation (10), we add five monthly lags of both the exchange rate change and the interaction of the exchange rate change with the imported intermediate goods cost share. We consider a regression of the form:

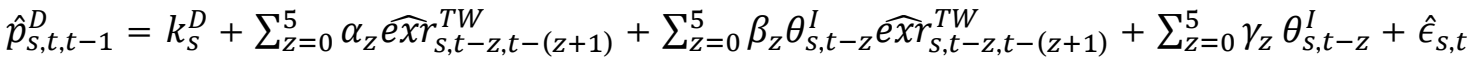

Specification (14) in Table 4 reports the sum of the six coefficients $\sum_{z=0}^{5} \alpha_{z}, \sum_{z=0}^{5} \beta_{z}$, and the corresponding standard errors.

Over a six-month horizon, imported input use can explain over one half of the correlation between import and producer prices for the mean sector in our data. The interaction coefficient is 0.61 , while the main effect is estimated to be statistically significant and positive at 0.08 . We note that, in our sample, the mean sector has a cost share of 0.17 . For this sector, the estimated rate of spillovers is equal to $0.08+0.17^{\star} 0.61=0.18$, of which $0.10=$ $0.17 * 0.61$, or over one half, can be attributed to the imported input cost channel.

The spillover to producer prices, derived from the long-run specification (10), can also be displayed graphically (Graph 5). We estimate the model for horizons from 0 to 24 months. The dashed line represents the estimated cumulative main effect, ie it is equal to $\sum_{z=0}^{k} \alpha_{z}$, with $k$ taking values from 0 to 24. The solid line is equal to the estimated effect for the median sector in our data set, ie $\sum_{z=0}^{k} \alpha_{z}+0.17 * \sum_{z=0}^{k} \beta_{z}$.

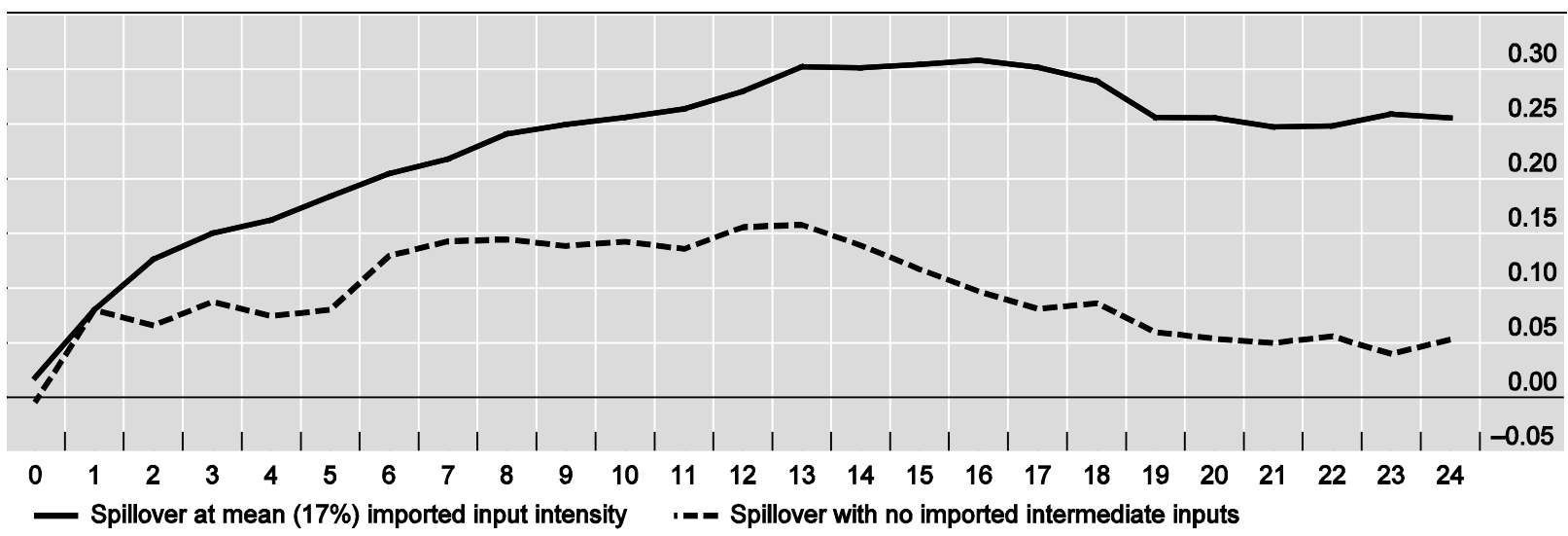

The graph displays the increase in producer prices resulting from a $1 \%$ depreciation in the trade-weighted exchange rate of the importing sector.

Source: Authors' calculations.

Graph 5 shows that a $1 \%$ depreciation of the trade-weighted exchange rate leads to a $0.25 \%$ increase in producer prices for the mean importing sector, ceteris paribus, within nine months of the exchange rate movement. After that, the impact stabilises, fluctuating between 0.25 and $0.30 \%$ at longer horizons. In contrast, for a sector that uses no imported inputs, the 
impact on producer prices reaches $0.15 \%$ after eight months, followed by stabilisation and a gradual decline to only $0.05 \%$. Again, these results emphasise the importance of the relative intensity with which the different sectors use imported inputs.

\subsection{Heterogeneous, asymmetric and non-linear responses}

The specifications so far have assumed linear and symmetric spillovers from exchange rate fluctuations to producer prices. Next, we investigate whether the impacts on producer prices vary for small and large exchange rate movements, and for positive and negative exchange rate fluctuations, respectively. We also examine whether the effects on producer prices are heterogeneous depending on country and industry characteristics.

We first evaluate whether increases in the costs of intermediate imported inputs have stronger impacts on producer prices than do decreasing costs. A reason for this is the inherent asymmetry in the profit function, whereby firms are more averse to goods being underpriced than overpriced. The maximum loss from underpricing could be unbounded, whereas the maximum loss from overpricing is limited by zero profits (see Devereux and Siu (2007)). As a result, it is likely that increases in costs of intermediate inputs will be passed through more fully to prices than decreasing costs.

Specifications (1) and (2) in Table 6 split the sample into appreciation episodes of the foreign exchange rate (resulting in decreasing costs of imported inputs) and depreciations (increasing import costs), respectively. This sample split documents that domestic prices do react strongly to increasing foreign input prices as a result of exchange rate depreciation, whereas no significant relation is found when foreign currencies become less expensive. The finding that producer prices react only to increasing costs of import prices emerges also at a six-month horizon. Here, we split the sample into periods in which the six-month cumulative change was below (3) or above (4) the median. Again, we find that the six-month cumulative effect of the cost change resulting from exchange rate movements is only significant for above-median cost changes, reflecting exchange rate depreciation (positive cost changes).

Is the response of domestic prices more pronounced when the magnitude of the exchange rate movement is large? In the presence of menu costs, whereby changing the price is costly, firms may allow their markups to absorb the effects of small changes in costs, keeping final prices constant. However, large changes in costs, possibly through sizeable shocks to the exchange rate, are more likely to lead to changes in final prices. 


\section{Asymmetries and non-linearities in the impact on producer prices}

\section{(1)-(4) asymmetric PPI response?}

\section{(5)-(8) non-linear PPI response?}

\begin{tabular}{|c|c|c|c|c|c|c|c|}
\hline $\begin{array}{l}\text { Negative exr } \\
\text { change }\end{array}$ & $\begin{array}{l}\text { Positive exr } \\
\text { change }\end{array}$ & $\begin{array}{l}\text { Below-median } \\
6 \mathrm{~m} \text { exr change }\end{array}$ & $\begin{array}{l}\text { Above-median } \\
6 \mathrm{~m} \text { exr change }\end{array}$ & $\begin{array}{l}\text { exr change } \\
\text { between } 25 \text { th } \\
\text { and } 75 \text { th } \\
\text { percentile }\end{array}$ & $\begin{array}{l}\text { exr change } \\
\text { below } 25 \text { th or } \\
\text { above } 75 \text { th } \\
\text { percentile }\end{array}$ & $\begin{array}{c}6 \mathrm{~m} \text { exr change } \\
\text { between } 25 \text { th } \\
\text { and } 75 \text { th } \\
\text { percentile }\end{array}$ & $\begin{array}{c}6 \mathrm{~m} \text { exr change } \\
\text { below } 25 \text { th or } \\
\text { above } 75 \text { th } \\
\text { percentile }\end{array}$ \\
\hline
\end{tabular}

\begin{tabular}{|c|c|c|c|c|c|c|c|c|}
\hline \multirow[b]{2}{*}{$\begin{array}{l}\text { Trade-weighted exchange rate change } \\
\text { (sector-specific weights) }\end{array}$} & \multicolumn{8}{|c|}{ Dependent variable is monthly \% change in sectoral PPI } \\
\hline & $\begin{array}{l}-0.011 \\
(0.046)\end{array}$ & $\begin{array}{l}-0.013 \\
(0.058)\end{array}$ & & & $\begin{array}{c}0.078 \\
(0.057)\end{array}$ & $\begin{array}{l}-0.006 \\
(0.016)\end{array}$ & & \\
\hline $\begin{array}{l}\text { Cost change from exchange rate }= \\
\Delta \text { exr } * \text { cost share }\end{array}$ & $\begin{array}{l}-0.134 \\
(0.079)\end{array}$ & $\begin{array}{l}0.372^{* * *} \\
(0.054)\end{array}$ & & & $\begin{array}{l}-0.117 \\
(0.200)\end{array}$ & $\begin{array}{l}0.125^{* *} \\
(0.043)\end{array}$ & & \\
\hline Imported input cost share & $\begin{array}{l}0.040 * * * \\
(0.008)\end{array}$ & $\begin{array}{l}-0.016 \\
(0.011)\end{array}$ & & & $\begin{array}{l}0.022 * * * \\
(0.003)\end{array}$ & $\begin{array}{l}-0.013 \\
(0.010)\end{array}$ & & \\
\hline $\begin{array}{l}\text { Six-month change in importer exchange } \\
\text { rate }\end{array}$ & & & $\begin{array}{l}0.306 * * * \\
(0.068)\end{array}$ & $\begin{array}{l}-0.131^{* * *} \\
(0.037)\end{array}$ & & & $\begin{array}{c}0.110 \\
(0.116)\end{array}$ & $\begin{array}{l}0.083^{* *} \\
(0.031)\end{array}$ \\
\hline $\begin{array}{l}\text { Six-month changes from exchange rate } \\
=\Delta \text { exr } * \text { cost share }\end{array}$ & & & $\begin{array}{l}-0.473 \\
(0.348)\end{array}$ & $\begin{array}{l}1.708^{* * *} \\
(0.095)\end{array}$ & & & $\begin{array}{l}-0.180 \\
(0.230)\end{array}$ & $\begin{array}{l}0.642^{* * *} \\
(0.144)\end{array}$ \\
\hline Time fixed effects & T-FE & T-FE & T-FE & T-FE & T-FE & T-FE & T-FE & T-FE \\
\hline Observations & 5,915 & 6,075 & 5,875 & 5,875 & 5,996 & 5,994 & 5,876 & 5,874 \\
\hline$R^{2}$ & 0.077 & 0.098 & 0.104 & 0.134 & 0.073 & 0.089 & 0.084 & 0.115 \\
\hline Number of panelvar & 89 & 89 & 89 & 89 & 89 & 89 & 89 & 89 \\
\hline
\end{tabular}


Specification (5) includes only those exchange rate movements that fall between the 25th and 75th percentiles, ie it includes only small fluctuations. In this specification, the interaction between exchange rates and the imported input cost share is not statistically significant. In contrast, in the sample of large movements (specification (6); exchange rate movement either below the 25th or above the 75th percentile), the latter interaction is statistically significant at the $5 \%$ level. Also, when evaluating at the six-month horizon, we find that there is no effect of the exchange rate interacted with the imported input cost share when the preceding six-month exchange rate change falls between the 25 th and 75 th percentiles (7). In contrast, there is a strong effect on prices in the sample where the preceding six-month exchange rate change is either below the 25 th or above the 75 th percentile (8).

Heterogeneous impacts on producer prices, distinct from the sign and magnitude of cost increases, are also possible. It is likely that both country and industry characteristics affect the rate at which price changes of imported input goods are passed on to domestic prices. Specifications (A1) to (A4) in Annex Table A1 examine whether there indeed exists such heterogeneity.

A first question of interest is whether industries that are characterised by different degrees of substitution for the output of the industry also differ in their response to cost changes. We split our sample of industries up by the elasticity of demand for the industry's output, using the sectoral elasticity estimates from Imbs and Méjean (2011). Consistent with the prior of most researchers, the impact of cost fluctuations on prices is higher in industries with elastic demand (specification (A1)) than with inelastic demand (specification (A2)). However, the coefficient is not estimated significantly in the elastic demand sample of specification (A1).

A second question concerns whether the effect differs across the economies in our sample that are quite heterogeneous in terms of openness to trade and financial openness. Given that our estimation strategy already accounts for differences in trade openness because lower openness leads to lower imported input intensity, we focus on financial openness.

In specifications (A3) and (A4), we split the sample up by financial openness. We use the Chinn and Ito $(2006,2008)$ index of financial openness, placing mainland China, India, Indonesia and Korea in the more closed group of economies and Australia, Chinese Taipei, and Japan in the financially more open group. This sample spilt reveals no difference in how imported input price changes affect domestic prices in these two groups of economies.

In addition to substitution effects that concern the substitutability of final goods when input prices change (as documented in specifications (A1) and (A2)), firms also substitute their inputs. In specification (A5), we explicitly control for the change in imported input costs, which would induce such substitution to domestic inputs and potentially affect domestic prices. We include the one-year change in the cost share, ie the one-year change in the absolute fraction of costs that is spent on imported inputs. This results in a positive coefficient: if the share of costs that is spent on imported inputs increases, so do prices.

Further, slow and pervasive structural transformations in the international production structure might have a long-lasting impact on the cost structure and price dynamics. In specification (A6), we thus also include the one- and two-year lags of the cost share change as independent variables. This uncovers no such long-term effects. We have also accounted 
for even longer-term development in the international production structure, also not uncovering any effect.

\subsection{Some policy implications}

The previous results show significant spillovers, especially over time, from costs of imported inputs to domestic producer prices in economies participating in the Asian supply chain. However, little so far has been said about the implications of the findings for monetary policy. Should monetary policymakers care about the behaviour of sectoral producer prices? After all, as the changes in sectoral prices represent relative price shifts, their effect on aggregate inflation may be muted.

In a model with menu costs, Ball and Mankiw (1995) argue that if the relative price shocks are large and affect the distribution of relative price changes, they will have an effect on aggregate inflation. Some studies emphasise the empirical relevance of large relative price changes for aggregate inflation (see Sekine (2009) and Auer and Fischer (2010)). ${ }^{14}$ On the other hand, Bryan and Cecchetti (1999) argue that the sample mean-skewness correlation suffers from a small sample bias.

Recall that in Section 2 we found a positive correlation between trade intensity and price comovement at the level of aggregate inflation, in terms of both producer and consumer prices. The sectoral analysis can then be seen as identifying one possible mechanism by which increased trade intensity leads to a closer co-movement of prices. It confirms that the results are not driven by common trends, but by the intensity with which different economies and sectors use imported intermediate inputs. Taken together, the results show that the economies and sectors more closely connected by trade experience greater price spillovers, even at the level of aggregate inflation.

\section{Conclusion}

When economies are becoming more globalised, disinflationary pressures from lower-cost imports are likely to contribute to lower domestic inflation, but this effect should be temporary. Once the economies are already closely interconnected (globalised), they are exposed to cross-border demand and supply shocks and the volatility of the domestic inflation rate could increase. We examine one such case of close interconnectedness, ie that of economies participating in the manufacturing supply chains in the Asia-Pacific region. In the sectoral analysis, we use the novel World Input-Output Database.

In the analysis using aggregate data, we find that both headline inflation rates and producer prices move more closely together between those Asian economies that trade more with one another, ie that share a higher degree of trade intensity. In the sectoral analysis, we have shown that the share of imported intermediate inputs in a sector's total variable costs is roughly $17 \%$ on average, for the seven Asia-Pacific economies. For the mean importing

\footnotetext{
${ }^{14}$ Sekine (2009) shows that global shocks to two relative prices - wage costs and import prices - account for an important share of disinflation in the OECD countries. Auer and Fischer (2010) show that comparative advantage-induced supply shocks in the emerging economies are likely to have affected aggregate inflation in the United States.
} 
sector in our data, when the exchange rate changes by $1 \%$, its producer prices change cumulatively by close to $0.3 \%$ during two years. ${ }^{15} \mathrm{An}$ important role is played by the intensity with which different sectors use imported intermediate inputs. This variation is mostly crosssectional (cross-sector and cross-economy), and therefore our results are not driven by common trends. This pinpoints the mechanism by which increased trade intensity leads to greater co-movement of prices.

In sum, real integration through the supply chain matters for domestic price dynamics in the Asia-Pacific region. They are also a concern for policymakers. Increased interconnectedness is likely to lead to greater sensitivity of aggregate inflation rates to costs of imported inputs, especially when the cost changes are large in magnitude.

${ }^{15}$ Computed at the mean imported-input intensity in our sample. 


\section{References}

Amiti, M, O Itskhoki and J Konings (2014): "Importers, exporters and exchange rate disconnect", American Economic Review, forthcoming.

Artis, M and T Okubo (2012): "Business cycle, currency and trade, revisited", Pacific Economic Review, 17(1), pp 160-80.

Auer, R, K Degen and A Fischer (2013): "Low-wage import competition, inflationary pressure, and industry dynamics in Europe", European Economic Review, 59, pp 141-66.

Auer, R and A Fischer (2010): "The effect of low-wage import competition on US inflationary pressure", Journal of Monetary Economics, 57, pp 491-503.

Auer, R and P Sauré (2014): "Price spillovers via the global supply network", Swiss National Bank, mimeo.

Baldwin, R and J López-González (2013): "Supply-chain trade: a portrait of global patterns and several testable hypotheses", CEPR Discussion Papers, no 9421.

Ball, L and G Mankiw (1995): "Relative-price changes as aggregate supply shocks", Quarterly Journal of Economics, 110(1), pp 161-93.

Bank for International Settlements (2009): "Globalisation, labour markets and international adjustment: essays in honour of Palle S Andersen", BIS Papers, no 50, December.

Baxter, M and M Kouparitsas (2005): "Determinants of business cycle comovement: a robust analysis", Journal of Monetary Economics, 52, pp 113-57.

Binici, M, Y-W Cheung and K Lai (2012): "Trade openness, market competition, and inflation: some sectoral evidence from OECD countries", International Journal of Finance and Economics, 17(4), pp 321-36.

Borio, C and A Filardo (2007): "Globalisation and inflation: new cross-country evidence on the global determinants of domestic inflation", BIS Working Papers, no 227, May.

Bryan, M and S Cecchetti (1999): "Inflation and the distribution of price changes", Review of Economics and Statistics, 81(2), pp 188-96.

Burstein, A, C Kurz and L Tesar (2008): "Trade, production sharing, and the international transmission of business cycles", Journal of Monetary Economics, 55(4), pp 775-95.

Chinn, $\mathrm{M}$ and $\mathrm{H}$ Ito (2006): "What matters for financial development? Capital controls, institutions, and interactions", Journal of Development Economics, 81(1), October, pp 163-92.

(2008): "A new measure of financial openness, Journal of Comparative Policy Analysis, 10(3), September, pp 309-22.

Ciccarelli, M and B Mojon (2010): "Global inflation", Review of Economics and Statistics, 92(3), pp 524-35.

Devereux, M and H Siu (2007): "State dependent pricing and business cycle asymmetries", International Economic Review, 47, pp 281-310. 
Di Giovanni, J and A Levchenko (2010): "Putting the parts together: trade, vertical linkages, and business cycle comovement", American Economic Journal: Macroeconomics, 2(2), pp 95-124.

Engel, C (2011): "Currency misalignments and optimal monetary policy: a reexamination", American Economic Review, 101, pp 2796-822.

Fauceglia, D, A Shingal and M Wermelinger (2013): "Natural hedging of exchange rate risk: the role of imported input prices", mimeo.

Feenstra, R and G Hanson (2004): "Intermediaries in entrepot trade: Hong Kong re-exports of Chinese goods", Journal of Economics and Management Strategy, 13(1), pp 3-35.

Goldberg, L and J Campa (2010): "The sensitivity of the CPI to exchange rates: distribution margins, imported inputs, and trade exposure", Review of Economics and Statistics, 92(2), pp 392-407.

Henriksen, E, F Kydland and R Sustek (2008): "The high cross-country correlations of prices and interest rates", NBER Working Papers, no 15123.

Hirakata, N, Y Iwasaki and M Kawai (2014): "Emerging economies' supply shocks and Japan's price deflation: international transmissions in a three-country DSGE model", $A D B I$ Working Papers, no 459.

Holz, C and A Mehrotra (2013): "Wage and price dynamics in a large emerging economy: the case of China", BIS Working Papers, no 409, April.

Imbs, J and I Méjean (2011): "Elasticity optimism", Paris School of Economics, mimeo.

International Monetary Fund (2013): "Trade interconnectedness: the world with global value chains", Policy Paper, September.

Johnson, R (2014): "Trade in intermediate inputs and business cycle comovement", American Economic Journal: Macroeconomics, forthcoming.

Laeven, L and F Valencia (2012): "Systemic banking crises database: an update, IMF Working Papers, 12/163.

Lipińska, A and S Millard (2012): "Tailwinds and headwinds: how does growth in the BRICs affect inflation in the G-7?", International Journal of Central Banking, 8(1), pp 227-66.

Milani, F (2009): "Does global slack matter more than domestic slack in determining US inflation?", Economics Letters, pp 147-51.

Monacelli, T and L Sala (2009): "The international dimension of inflation: evidence from disaggregated data", Journal of Money, Credit and Banking, 41(1), pp 101-20.

Mumtaz, H and P Surico (2012): "Evolving international inflation dynamics: world and country-specific factors", Journal of the European Economic Association, 10(4), pp 716-34.

Rogoff, K (2003): "Globalisation and global disinflation", paper prepared for the Federal Reserve Bank of Kansas City conference on Monetary Policy and Uncertainty: Adapting to a Changing Economy, Jackson Hole, 29 August. 
Sekine, T (2009): "Another look at global disinflation", Journal of the Japanese and International Economies, 23, pp 220-39.

Stock, J and M Yogo (2005): "Testing for weak instruments in linear IV regression", in D Andrews and J Stock (eds), Identification and inference for econometric models: essays in honor of Thomas Rothenberg, Cambridge: Cambridge University Press, pp 80-108.

Timmer, M, A Erumban, B Los, R Stehrer and G de Vries (2013a): "Slicing up global value chains", mimeo.

(2013b): "Fragmentation, incomes and jobs: an analysis of European competitiveness", mimeo.

Tootell, G (1998): "Globalization and US inflation", New England Economic Review, July/August, pp 21-33.

WIOD (2012): The World Input-Output Database (WIOD): Contents, Sources and Methods, www.wiod.org. 


\section{Appendix}

Heterogeneity in the impacts on producer prices

Table A1

(1)

Industries

with elastic

demand
(2)

Industries with inelastic demand
(3)

Financially open economies
(4) Financially closed economies
(5)

Using onyear change in cost share
(6)

Using lags

of changes

in cost share

Dependent variable is monthly \% change in sectoral PPI

\begin{tabular}{lcccccc}
\hline Trade-weighted exchange rate & -0.035 & 0.006 & 0.002 & -0.030 & -0.014 & $-0.045^{* * *}$ \\
change (sector-specific weights) & $(0.036)$ & $(0.019)$ & $(0.010)$ & $(0.036)$ & $(0.012)$ & $(0.014)$ \\
\hline Cost change from exchange rate & 0.194 & $0.130^{* *}$ & $0.146^{* * *}$ & 0.148 & $0.154^{* * *}$ & $0.219 * * *$ \\
$=\Delta$ exr * cost share & $(0.200)$ & $(0.041)$ & $(0.032)$ & $(0.090)$ & $(0.047)$ & $(0.056)$ \\
\hline Imported input cost share & $0.029 * * *$ & 0.005 & 0.007 & $0.015^{*}$ & $0.035^{* * *}$ & $0.035^{* * *}$ \\
& $(0.007)$ & $(0.004)$ & $(0.008)$ & $(0.008)$ & $(0.010)$ & $(0.011)$ \\
\hline $\begin{array}{l}\text { One-year lag of cost share } \\
\text { change }\end{array}$ & & & & -0.011 \\
\hline $\begin{array}{l}\text { Two-year lag of cost share } \\
\text { change }\end{array}$ & & & & & $(0.013)$ \\
\hline Observations & & & & & 0.014 \\
\hline $\mathrm{R}^{2}$ & 6,083 & 5,907 & 5,702 & 6,288 & 11,462 & $(0.013)$ \\
\hline Number of panelvar & 0.002 & 0.003 & 0.003 & 0.001 & 0.003 & 0.003 \\
\hline
\end{tabular}

Dependent variable is the change in the importer's PPI. Heteroscedasticity-robust standard errors clustered by industry are reported in parentheses below the coefficient estimates. ${ }^{* * *} p<0.01,{ }^{* *} p<0.05, * p<0.1$. 


\section{Sample information for Table 1}

The estimation samples of models 1-3 and 6-8 in Table 1 are adjusted to correspond to the availability of money stock data. The start dates of the estimation samples are as follows:
AU Q1 1980
CN Q1 1996
ID Q1 1981
IN Q2 1991
JP Q1 1980
KR Q1 1980
MY Q4 1985
NZ Q1 1989
$\mathrm{PH} \quad \mathrm{Q} 11981$
TH Q1 1996

For the country pair of the Philippines and Indonesia, data for 1996 are missing.

The estimation samples of models 4-5 and 9-10 in Table 1 are adjusted to correspond to the employment data. The start dates of the estimation samples are as follows:
AU Q1 1981
CN Q1 1996
ID Q1 1989
IN Q2 1991
JP Q1 1981
KR Q1 1981
MY Q1 1986
NZ Q1 1981
$\mathrm{PH} \quad \mathrm{Q} 11986$
TH Q1 1996

For India, data for 2012 are missing. 